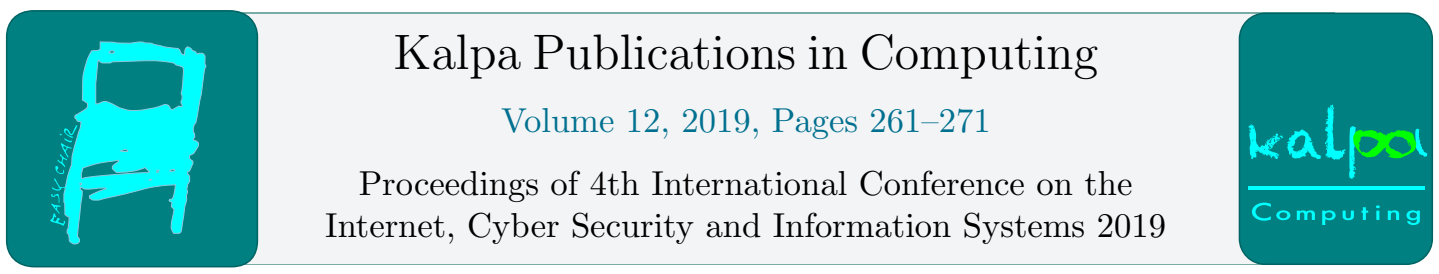

\title{
An investigation of the level of e-health literacy in South Africa
}

\author{
Dolly Posiliti ${ }^{1}$ and Liezel Cilliers ${ }^{1}$ \\ ${ }^{1}$ University of Fort Hare, South Africa \\ lcilliers@ufh.ac.za
}

\begin{abstract}
E-health resources are widely used in the healthcare field, by health professionals, patients and the general public. However, to utilise e-health resources an individual needs to possess the basic e-health literacy skills that will enable them to process health information effectively. E-health literacy consists of six basic literacy skills namely traditional and numeracy skills, computer, media, science, in-formation and health literacy skills that individuals need to possess in order to use e-health resources effectively. The concept of e-health literacy is a growing field of research worldwide but has lacked investigation in South Africa. This paper investigated the level of e-health literacy skills of South Africans. The study made use of a qualitative, inductive research approach and a structured literature review to identify the relevant academic studies that have been done in South Africa. Eleven studies were included in the final analysis. The study found that only parts of the e-health literacy skills have been investigated in South Africa, and it was concluded that South Africans have limited skills that enable them to seek health information independently. The study recommends that the lev-el of e-health literacy among South African be improved through education and awareness campaigns that highlight the importance of taking control of owns health in order to improve the health of all South Africans.
\end{abstract}

Keywords: E-health; e-health literacy; South Africa

\section{Introduction}

Literacy is one of the fundamental attributes that individual's in a society are expected to possess. Literacy is characterised by an individual's ability to read, write and understand a certain kind of information (Bau-tista, 2015). Individuals all over the world learn new skills every day to improve their way of life. This includes health literacy, which helps individuals to take ownership of their own health. Health literacy refers to an individual's ability to understand healthcare information and be able to apply that information for decision making in their health care (Bress, 2014). According to Dinya, (2013) health literacy is an important skill needed to achieve positive health outcomes for personal and 
community growth. In the South African context, the concept of health literacy has been a growing field of research (Volmink, 2018).

Health literacy is needed to understand and interpret vast amounts of information from numerous sources. Health literacy is also essential for effective communication between a patient and a medical practitioner. Health sources vary from books and other printed material such as pamphlets, peer to peer communication, internet and other digital technologies that deliver health information (Johannah \& Swartz, 2013). All these sources need the ability to read, understand and apply health information to make positive health decisions (De Choudhury, Morris, \& White 2014). However, using the internet and other digital platforms also need an individual to be able to interact with electronic platforms in order to understand health information. Therefore, the use of the internet to access and use health information requires an individual to have electronic health (e-health) literacy (Tennant et al., 2015).

Norman and Skinner (2006) first introduced E-health literacy. E-health literacy is different from health literacy because it includes acquiring health information using digital technology. E-health literacy has become an important concept in healthcare as technology evolves and people move away from traditional methods of seeking health in-formation to using the internet to find answers to their questions. Nor-man and Skinner (2006:02) defined e-health literacy as "the ability to seek, find, understand, and appraise health information from electronic sources and apply the knowledge gained to addressing or solving a health problem.” This definition has been a useful tool among re-searchers in the development of skills needed to utilise e-health re-sources. Bautista (2015) criticised the definition of e-health literacy by Norman and Skinner (2006), claiming that the definition is only limited to the decision making of an individual, Bautista (2015), further ex-plains that the definition should be extended to be more goal-oriented in improving and shaping the e-healthcare as a whole rather than being concerned about solving a single health problem of an individual. Bautista (2015:39), further proposed a new definition for e-health literacy that states that "e-health literacy involves the interplay of individual and social factors in the use of digital technologies to search, acquire, comprehend, appraise, communicate and apply health information in all contexts of healthcare with the goal of maintaining or improving the quality of life throughout the lifespan.” The definition introduces social factors such as religion, economic status, etc. as the determinants of e-health literacy social factors.

E-health literacy consists of six basic literacy skills that include traditional and numeracy, computer, media, science, information and health literacy skills (Islam et al., 2017). The growing use of the internet has encouraged individuals worldwide to use the internet to search for health information. However users who choose to use the internet to search for health information, need to be able to use the electronic de-vice effectively to be able to navigate the internet to find the information. Additionally users must be able to process the health information correctly and make effective health decision. Previous studies indicate that users who make use of electronic resources to seek health information are not necessarily equipped with the required skills (Norgaard, Furstrand, Klokker, Karnoe, Batterham, Kayser, Osbornet, 2015). This may pose more threats to the users health issues if they misinterpret the information they find which could lead to increased hospitalization and deaths. Worldwide it has been identified that users often use the internet as the first step to educate themselves about health issues they experience. In South Africa, there has been no re-search pertaining to e-health literacy, hence for the purpose of this study, the literature reviewed each basic e-health literacy skills that have been investigated in South Africa so that the combination of all these literacy skills could provide the level of e-health literacy South Africans possess. The following section provides background information on the different e-health skills and what they pertain. 


\section{E-health literacy skills}

The six different types of e-health literacy presented in Figure 1 pro-vide the foundational skills required to optimize e-health. Lack of these foundational skills for e-health literacy may pose a challenge to individuals using e-health resources to obtain health information. For example, individuals who are not computer literate may have a challenge in seeking and accessing health information in online sources. Therefore, the concept of e-health literacy will not have an effect on their lives and they will still rely on traditional sources to access health information. Figure 1 below shows the e-health literacy skills.

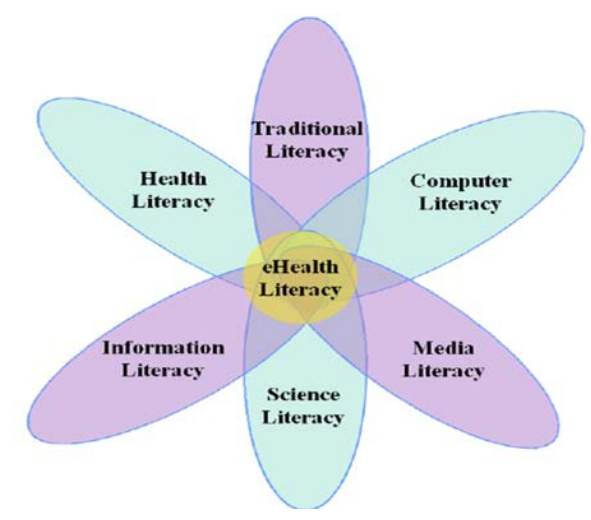

Figure 1: e-health literacy Lily Model (Tennant et al., 2015)

- Traditional and numeracy literacy skills refer to the ability to read the text, understand it and be able to speak and write the language in a logical manner (Haskins et al., 2017)

- Computer literacy is the necessary skills needed to use a computer or other digital platforms to solve a problem. This also refers to new technologies and software is needed in problem solving. (Britt, et al., 2007).

- Media literacy- is the ability to take different types of mediums and be able to differentiate the message each medium sends (Oakleaf, 2009). Media literacy enables the placement of in-formation in a social and political context and to consider issues such as the audience relations, and how media forms in them-selves and shapes the message that is conveyed.

- Science literacy is the required understanding and knowledge of scientific processes commonly used in healthcare in order to use the information for personal decision-making (Johannah \& Swartz, 2013).

- Information literacy includes skills for the ability to seek relevant information, to separate and organize the information into knowledge and use to educate others.

- Health literacy refers to the necessary skills needed to interact with healthcare systems (Britt, et al., 2007). These skills re-quire the ability to read and understand health-related information and be able to perform numeracy tasks required in the health environment. (Tennant et al., 2015). 


\section{Methodology}

The study adopted the interpretivist paradigm and a qualitative inductive research approach. The study collected data through a systematic review of South African literature that has investigated the literacy skills needed to utilise e-health resources. The articles were screened and analysed to find the most suitable studies that answer the research.

The authors used the following databases as the sources of the literature analysed in the study: Google Scholar, Science Direct, the PubMed Library, Research Gate, Association for Computing Machinery (ACM), Taylor and Francis and Wiley Online Library. The keywords and combination of keywords that were used during the literature search is presented in Table 1 . The selected articles were checked for duplications, sorted by relevance and year. Articles older than 10 years were re-moved. For further screening, the articles were checked if they fall under the literacies in the healthcare of South Africa. Articles who did not meet this criterion were further eliminated in the study.

Table 1: Keywords used to extract information from the databases

\begin{tabular}{|l|l|}
\hline $\begin{array}{l}\text { Search Phrase } \\
\text { Round 1 }\end{array}$ & Reason for modifying \\
\hline $\begin{array}{l}\text { e-health literacy } \\
\text { Traditional and numeracy literacy } \\
\text { Computer literacy } \\
\text { Media literacy } \\
\text { Science literacy } \\
\text { Health literacy } \\
\text { Information literacy }\end{array}$ & The original phrase used to search in \\
\hline Round 2 + South Africa & \\
\hline & \\
\hline
\end{tabular}

The screening process of the articles followed four processes Identification, screening, eligibility and Included. 


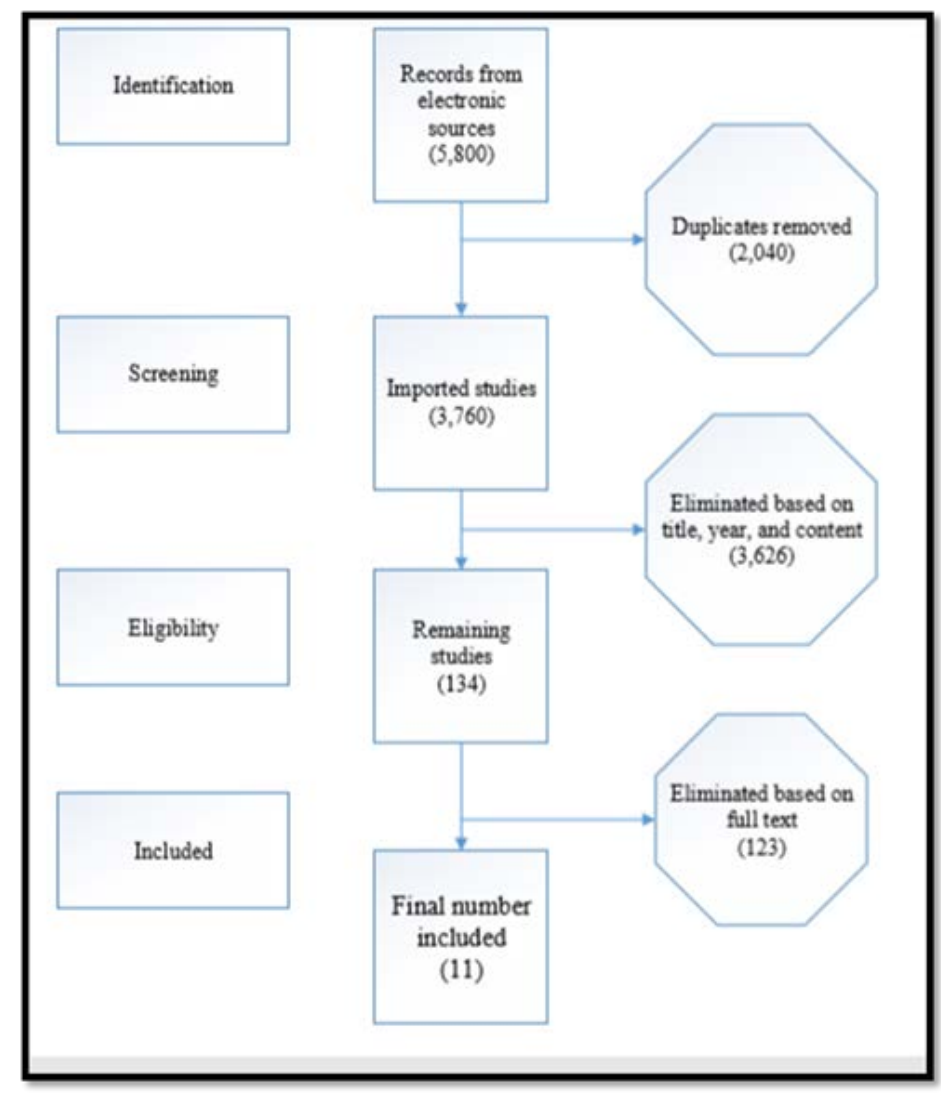

Figure 1: Data collection process

The eleven articles, which were chosen after the screening process, are presented in the table below: Table 1: Eleven articles included in the study

\begin{tabular}{|c|c|l|c|c|}
\hline No: & Author & \multicolumn{1}{|c|}{ Title } & Location & Year \\
\hline 1. & $\begin{array}{c}\text { Johannah } \\
\text { \& Swartz }\end{array}$ & $\begin{array}{l}\text { Lost opportunities to } \\
\text { improve health literacy: } \\
\text { Observations in a chronic } \\
\text { illness clinic providing care for } \\
\text { patients with epilepsy in Cape } \\
\text { Town. }\end{array}$ & $\begin{array}{c}\text { South } \\
\text { Africa }\end{array}$ & 2013 \\
\hline 2. & Benatar & $\begin{array}{l}\text { The challenges of health } \\
\text { disparities in South Africa }\end{array}$ & $\begin{array}{c}\text { South } \\
\text { Africa }\end{array}$ & 2013 \\
\hline 3. & Hill & $\begin{array}{l}\text { Promoting healthy lifestyle } \\
\text { behaviour through the Life- } \\
\text { Orientation South } \\
\text { Teachers perceptions of the } \\
\text { Health Kick intervention. }\end{array}$ & $\begin{array}{c}\text { Sfrica } \\
\text { African }\end{array}$ & 2015 \\
\hline 4. & Asah & $\begin{array}{l}\text { Computer usage among } \\
\text { nurses in rural health-care } \\
\text { facilities in South Africa: } \\
\text { obstacles and challenges. }\end{array}$ & $\begin{array}{c}\text { South } \\
\text { Africa: } \\
\text { Durban }\end{array}$ & 2013 \\
\hline
\end{tabular}




\begin{tabular}{|c|c|c|c|c|}
\hline 5. & Boakye & $\begin{array}{l}\text { The social dimension of } \\
\text { reading literacy development in } \\
\text { South Africa: Bridging } \\
\text { inequalities among the various } \\
\text { language groups. }\end{array}$ & $\begin{array}{l}\text { South } \\
\text { Africa }\end{array}$ & 2015 \\
\hline 6. & Volmink & $\begin{array}{l}\text { Reconceptualising health } \\
\text { professions education in South } \\
\text { Africa. }\end{array}$ & $\begin{array}{l}\text { South } \\
\text { Africa }\end{array}$ & 2018 \\
\hline 7 & \begin{tabular}{l}
\multicolumn{1}{c}{ Taylor, } \\
Jinabhai, \\
Sathiparsad, \\
and Vries
\end{tabular} & $\begin{array}{l}\text { South African high school } \\
\text { students' health literacy and } \\
\text { behaviour } \\
\text { HIV/AIDS, STIs, and TB } \\
\text { (HAST. }\end{array}$ & $\begin{array}{l}\text { South } \\
\text { Africa }\end{array}$ & 2014 \\
\hline 8. & Mokwena & $\begin{array}{l}\text { Strategies to increase the } \\
\text { health literacy needed to } \\
\text { complement health-promoting } \\
\text { legislation in South Africa. }\end{array}$ & $\begin{array}{l}\text { South } \\
\text { Africa }\end{array}$ & 2015 \\
\hline 9. & $\begin{array}{l}\text { Thompson, } \\
\text { Havenga, and } \\
\text { Naude }\end{array}$ & $\begin{array}{l}\text { The health literacy needs of } \\
\text { women living with HIV/AIDS. }\end{array}$ & $\begin{array}{l}\text { South } \\
\text { Africa }\end{array}$ & 2015 \\
\hline 10 & \begin{tabular}{l}
\multicolumn{1}{c}{ Wessels, } \\
Mnkeni- \\
Saurombe and \\
Knoetze
\end{tabular} & $\begin{array}{l}\text { Narratives of information } \\
\text { literacy in South African } \\
\text { township schools. }\end{array}$ & $\begin{array}{l}\text { South } \\
\text { Africa }\end{array}$ & 2014 \\
\hline 11. & Bress & $\begin{array}{l}\text { Developing a framework to } \\
\text { identify and respond to health } \\
\text { literacy needs using } \\
\text { community-based emergency } \\
\text { first aid responders in the } \\
\text { lavender hill. }\end{array}$ & $\begin{array}{l}\text { South } \\
\text { Africa }\end{array}$ & 2014 \\
\hline
\end{tabular}

\section{Results and discussion}

\subsection{Traditional and numeracy literacy in South Africa}

Traditional and numeracy literacy is a fundamental skill needed for the ability to read, write and understand a certain kind of information (Boakye 2015). The ability to read and write however does not necessarily mean that individuals are able to evaluate health information within the health care systems (Thompson, Havenga, \& Naude, 2015). According to Hill, (2015), general health information is taught to young people at school and in the community in order to decrease the infection and spread of germs and bacteria's. Additionally, further trainings are also held for the elderly who are illiterate to educate them about arising health conditions, these trainings are held in the forms of as sanitation projects and farming trainings in rural and informal settlements from NGO'S such as Love Life (Mokwena 2015: Department of Health 2016). These trainings make use of pictures and storytelling for illiterate people to teach the community the important health information such as of washing hands before eating and after using the bathroom (Healthy \& Programmesouth, 2013). According to School Health, (2016) South African schools provide adequate teaching about health education through the 
curriculum presented in the life orientation and Life skills subjects, the elderly people are taught about healthy living in their communities through hospital-based community outreach projects. Hill, (2015) concluded that South Africans have adequate traditional literacy when it comes to healthcare. Furthermore according to Stats SA (2015) the literacy rate in South Africa was 94.37\%; even so, the small group of people which cannot read and write they have knowledge about staying healthy and are knowledgeable about the prevention and treatment of the common health issues that mainly affect the Southern Africa region (Thompson et al., 2015). These individuals can also differentiate the symptoms of colds and fevers that need medical attention (Taylor, Jinabhai, Sathiparsad, \& Vries, 2014)

\subsection{Computer literacy in South Africa}

Computer literacy in healthcare refers to the ability of healthcare professionals and patients to use healthcare systems and the internet to gather health information (Boakye, 2015). According to a report by the Basic Education in 2008, South Africa had the lowest computer literacy skills in the world. Over 90 percent of schools had no computer facilities for students to learn computer literacy. Currently, according to digital statistics 2016/2017 South Africa and Africa as a whole rely on mobile phones. Many South Africans encounter a computer for the first time when they leave high school either when they start University or at a workplace. This, therefore, means South Africans use a computer only to carry out work/school related matters (Asah, 2013). Thus, patients and the general public who do not work with health systems have limited knowledge to use a computer for activities that may serve their health (Thomas, 2016: Mokwena, 2015).

\subsection{Media literacy in South Africa}

Media literacy within the healthcare sector allows an individual to access, analyse and evaluate health information from a variety of media sources (Akbarinejad, Soleymani, \& Shahrzadi, 2017). Media literacy allows individuals to create and exchange messages with the internet and other technologies, printed and non-printed material for easier access to health information. South African healthcare has expanded media literacy from health professionals to the general public to promote equal distribution of health technologies. The focal point is to offer accessible e-health resources to all South Africans. Accessible health information can empower all the people of South Africa through integrated health systems. South Africans have adequate skills that allow them to actively engage in media platforms, however, they still lack the skills to use the media for health information (Asah, 2013:Digital statistics 2016/2017). Media literacy in healthcare allows patients to have personalised e-health records and accessible health files anytime. Media platforms include applications that manage fit-ness (fitness apps) systems that calculate and manage cholesterol in-take, calculate body mass index BMI and suggest better ways of life-style. According to ( Wessels, Mnkeni-Saurombe and Knoetze \& 2014) although these apps are available and accessible in South Africa, South Africans they still show difficulties engaging in them and lack understanding of what these media platforms entail.

\subsection{Science literacy in South Africa}

Science literacy refers to an individual's level of knowledge of scientific health principles that an individual possess for personal decision-making (Drummond \& Fischhoff, 2017). Science literacy in healthcare means an individual can find solutions to healthcare questions that need answers. Science literate people have the ability to predict natural phenomena (Ho, Leong, Looi, Chen, \& Pang, 2018). Webb, (2017) reports that South Africans show poor performance in terms of science-related education; this is due to facts such as language use. South Africa uses English, which is a second language for the majority of both teachers and learners to teach and learn science. Webb, (2017), further claims that the poor response to health science literacy in South African especially the black community can be traced 
to Apartheid legislations where certain groups were restricted to a certain level of learning. According to Gastrow, Juan, and Roberts, (2013) the attitudes towards science literacy have improved significantly since the year 1999. According to Science Engagement Strategy, (2015) South Africans are slowly becoming health, science and technologically literate population. Therefore, it can be concluded that South Africa is still moving towards becoming a health science literate nation.

\subsection{Health literacy in South Africa}

Health literacy does not only refer to the ability to read and write but to be able to interpret health information including nutritional information. Health literacy skill enables a person to navigate health information in order to make informed decisions (Greenberg \& Feinberg, 2018). A health literate person is able to understand cause and effect relationships between the action and the results (Apfel \& Tsouros, 2017). According to Johannah \& Swartz, (2013), although South Africa has a high level of general literacy, it is still severely affected by diseases and traumatic injuries. It is believed that this is affected by a distinct form of literacy that lacks amongst South Africans that is health literacy (Benatar 2013). Poor health literacy is associated with poor health decisions about prevention, treatment and coping with certain health conditions (Apfel \& Tsouros, 2017). Poor management of health conditions leads to increased hospitalisations and deaths. According to (Asah, 2013) in South Africa health literacy contributes to the health inequalities among racial or ethnical groups, different levels of education and social and economic statuses. Boakye, (2015) claims that South Africa is diverse, each population group shows different responses to health literacy. According to a study carried out in Cape Town South Africa, The highly educated individuals in the corporate world rely on and trust medical professionals for health information. However, this group although characterised by highly educated people they still do not go an extra mile to educate themselves about health information, but only about the conditions diagnosed to them by medical professionals in order to improve in that one particular condition. The poorly literate population that mostly resides in the townships, in-formal settlements and rural areas have knowledge about the common conditions such as HIV/AIDS, TB, Diabetes, Strokes e.t .c. However, this group knows about the conditions, prevention, treatment and coping mechanisms because South Africa is one of the countries in the world with a highest HIV/AIDS rate and people living with this condition are mostly found in townships and informal settlements (Otwombe et al., 2015). Wentzel \& Voce, (2012) claims that since the widespread of HIV and other chronic diseases local clinics and NGO's have been providing education to people living with these conditions and the whole communities that live amongst these people. Therefore, even the poor and illiterate have a certain degree of health literacy to conditions common within their communities. This health information includes living with people with these conditions, the prevention of the spread of the condition, early symptoms of the condition and the treatment of the condition, trainings related to cardiopulmonary resuscitation (CPR) (Health Annual Report, 2015). Otwombe et al., (2015) claims that the overall health literacy in South Africa is limited everyone is concerned only about what is common and what they have been diagnosed with, and they still heavily rely on health professionals for guidance and coping mechanisms (Benatar, 2013).

\subsection{Information literacy in South Africa}

Information literacy defined as a crucial skill needed to understand the "need for information the resources available, how to find information, the need to evaluate results, how to work with or exploit results, ethics and responsibility of use, how to communicate or share your findings, how to manage your findings” (Kanyengo, 2007, p. 02). Information literacy in healthcare is important because individuals have to be able to navigate around the growing health information (Wessels, Mnkenisaurombe, \& Knoetze, 2014). Health information in libraries, internet or other media sources is available in unfiltered formats; therefore, individuals should be able to differentiate the information 
valid from invalid for their health needs (Middelweerd et al., 2014). According to Johannah and Swartz, (2013) tremendous progress has been made in South Africa for the public to access health information from multiple sources of information; however, factors such as the language, literacy levels hinder the distribution of health information literacy. An information literate individual is characterised by the ability to analyse vast information for decision-making. According to Gathoni, (2012) South African health professionals also show a certain level of discomfort in filtering and analysing certain kinds of in-formation, especially health information that is obtained through digital platforms (Boakye, 2015).

The literature skills that lack research in South African healthcare are science and information literacy skills. Only the traditional and numeracy skills present adequate literacy to utilise e-health resources. From the overall articles reviewed in this study, it can be concluded that South Africa does not have the literacy skills needed utilise e-health resources. It can also be noted that the possession of literacy kills may vary for each individual depending on their age group, level of education or even profession. For instance, the health and medical professionals have a higher degree in traditional and numeracy and health literacy; however, they still lack the computer and media skills. Young people show adequate skills for traditional and numeracy, computer and media skills, however, they lack health skills, therefore even though they have means to seek health information from different sources of information, they cannot process the health information they find in electronic sources. The elderly with poor traditional literacy have knowledge about the diseases they suffer from through the help of the teachings from health professionals.

\section{Conclusion}

This research study sought to identify the level of e-health literacy that South Africans possess. Ehealth literacy is characterised with the ability to use e-health resources for decision-making. The study made use of secondary data that has been collected and drew relevant conclusions from the literature available. The authors took different literacy skills that have been investigated in the healthcare sector of South Afri-ca. The literature available in the literacy skills was used to determine whether South Africans have relevant skills that enable them to utilise e-health resources independently for decisionmaking. The study identified that in the field of healthcare, the Science and Information literacy skills lack investigation, the authors did not find relevant literature that specifically investigates these literacy skills in the healthcare of South Africa. In other literacy skills, South Africans show limited literacy that enables them to seek health information independently. The lack of skills affects the implementation and distribution of e-health resources in South Africa. For future research, this study recommends that an instrument is used to measure the degree of e-health literacy that South Africans possess. This could be done by observations in interactions of South Africans with the health systems.

\section{Acknowledgements}

This research project was jointly funded by the South African Medical Research Council (SAMRC) and Forte, the Swedish Research Council for Welfare, Working Life and Welfare. 


\section{Reference List}

Akbarinejad, F., Soleymani, M. R., \& Shahrzadi, L. (2017). The rela-tionship between media literacy and health literacy among preg-nant women in health centers of Isfahan. J Edu Health Promot, 6(1), 6-17.6 1 / 5. (2015).

Africa, S. (n.d.). PROMOTING HEALTHY, 1-33.

Apfel, F., \& Tsouros, A. D. (n.d.). Health literacy The solid facts.

Asah, F. (2013). Computer usage among nurses in rural health-care facilities in South Africa: obstacles and challenges, 499-510. https://doi.org/10.1111/j.1365-2834.2011.01315.x

Boakye, N. (2015). The social dimension of reading literacy development in South Africa : Bridging inequalities among the various language groups, 133-156. https://doi.org/10.1515/ijsl-2015-0008

Drummond, C., \& Fischhoff, B. (2017). Individuals with greater science literacy and education have more polarized beliefs on controversial science topics, (19). https://doi.org/10.1073/pnas.1704882114 8.

Gastrow, M., Juan, A., \& Roberts, B. (2013). Public attitudes to science in South Africa, 109(1), 1-

Greenberg, D., \& Feinberg, I. Z. (2018). Adult literacy: a perspective from the United States. https://doi.org/10.1007/s11618-018-0853-8

Haskins, L., Grant, M., Phakathi, S., Wilford, A., Jama, N., \& Horwood, C. (2017). Insights into health care seeking behaviour for children in communities in KwaZulu-Natal, South Africa. African Journal of Primary Health Care \& Family Medicine, 9, e1-e9. https://doi.org/10.4102/phcfm.v9i1.1378 [doi]

Healthy, T. H. E., \& Programmesouth, S. (n.d.). THE HEALtHY SCHOOLs PROGRAMME.

Hill, J. (2015). Promoting healthy lifestyle behaviour through the Life-Orientation curriculum: Teachers ' perceptions of the HealthKick intervention, 35(1), 1-9.

Ho, S. S., Leong, A. D., Looi, J., Chen, L., \& Pang, N. (2018). Science Literacy or Value Predisposition? A Meta- Analysis of Factors Predicting Public Perceptions of Benefits, Risks , and Acceptance of Nuclear Energy Factors Predicting Public Perceptions of Benefits, Risks , and. Environmental Communication, 0(0), 1-15. https://doi.org/10.1080/17524032.2017.1394891

Johannah, M., \& Swartz, L. (2013). Epilepsy \& Behavior Lost opportunities to improve health literacy: Observations in a chronic illness clinic providing care for patients with epilepsy in Cape Town South Africa. Epilepsy \& Behavior, 26(1), 36-41. https://doi.org/10.1016/j.yebeh.2012.10.015

Middelweerd, A., Mollee, J. S., Wal, C. N. Van Der, Brug, J., \& Velde, S. J. (2014). Apps to promote physical activity among adults : a review and content analysis, 1-9. https://doi.org/10.1186/s12966014-0097-9

Norgaard, O., Furstrand, D., Klokker, L., Karnoe, A., Batterham, R., Kayser, L., \& Osborne, R. H. (2015). The e-health literacy framework: A conceptual framework for characterizing e-health users and their interaction with e-health systems. Knowledge Management and E-Learning, 7(4), 522-540.

Norman, C. D., \& Skinner, H. A. (2006). eHealth literacy: Essential skills for consumer health in a networked world. Journal of Medical Internet Research, 8(2), 1-11. https://doi.org/10.2196/jmir.8.2.e9

Oakleaf, M. (2009). Writing information literacy assessment plans: A guide to best practice. Communications in Information Literacy, 3(2), 80-90. https://doi.org/10.1002/asi

Otwombe, K., Dietrich, J., Laher, F., Hornschuh, S., Nkala, B., Chimoyi, L., ... Miller, C. L. (2015). Health-seeking behaviours by gender among adolescents in Soweto, South Africa. Global Health Action, 8(1), 2-11. https://doi.org/10.3402/gha.v8.25670

Science Engagement Strategy. (n.d.).

Taylor, M., Jinabhai, C., Sathiparsad, R., \& Vries, H. De. (2014). Type : Poster Presentation Type : Poster Presentation. International Journal of Infectious Diseases, 21, 247. https://doi.org/10.1016/j.ijid.2014.03.934 
Tennant, B., Stellefson, M., Dodd, V., Chaney, B., Chaney, D., Paige, S., \& Alber, J. (2015). eHealth literacy and Web 2.0 health information seeking behaviors among baby boomers and older adults. Journal of Medical Internet Research, 17(3), 1-16. https://doi.org/10.2196/jmir.3992

Thomas, S. (2016). An analysis of the adoption of electronic health records in primary healthcare, (January).

Thompson, J., Havenga, Y., \& Naude, S. (2015). ScienceDirect The health literacy needs of women living with HIV / AIDS. Health SA Gesondheid, 20(1), 11-21. https://doi.org/10.1016/j.hsag.2015.03.001

Webb, P. (2017). Science education in South Africa: Issues of language and scientific literacy ., (January).

Wentzel, D., \& Voce, A. (2012). Health Seeking Experiences and Behaviours of Homeless People in Durban, South Africa. Africa Journal of Nursing and M Dwifery, 14(2), 1682-5055.

Wessels, N., Mnkeni-saurombe, N., \& Knoetze, H. (2014). Narratives of Information Literacy in South African Township Schools Narratives of Information Literacy in South African Township Schools, (January 2016). https://doi.org/10.1007/978-3-319-14136-7

Zhang, Y. (2013). College students' uses and perceptions of social networking sites for health and wellness information. Information Research, 17(3), 1-19. Retrieved from http://www.informationr.net/ir/17-3/paper523.html 